Naples, to be established in Northern Europe, it would be difficult to find a spot so admirably fitted as Lervik, on account of the richness of its fauna, and especially in view of the fact that the deep-sea fauna is brought almost to the door by the peculiar condition of the fjords, dredging up to 400 or 500 fathoms being attainable a few miles up the Hardanger.

E. RAY LANKESTER

Lervik, Stordoe, near Bergen, Norway, August 27

\section{SCIENTIFIC RESULTS OF THE "JEANNETTE" EXPEDITION}

THE last number (August 26) of Der Naturforscher contains a first attempt to lay down the scientific results of this expedition, in a paper by Herr $\mathrm{H}$. Wichmann, based on the reports of Messrs. Melville and Danenhauer, and of the naturalist of the expedition, $\mathrm{Mr}$. Newcomb. It is known that after having passef, on August 3I, the wintering station of the Vega, the Jeannette sailed north, towards Wrangel's Land. But on September 5, when twenty miles north-east of Herald Island, she was frozen in, and during twenty-one months remained so, "the play of winds and currents." However drifted in different directions, she still advanced during all this time towards the north-west. The first wintering was north of Wrangel Land, which last proved to be a large island, and not a part of an Arctic continent as had been presumed. The precious observations on auroræ and magnetism which were made during the winter (about 2000 measurements) are unhappily lost, as well as extensive collections of birds and of deep-sea fauna. The depth of the ocean in these regions was everywhere very small-thirty fathoms on an average, with a maximum of sixty and a minimum of seventeen fathoms. The bottom was usually a blue ooze, with a few shells and sometimes stones, which seemed to be of meteoric origin.

The ship still drifted towards the north-west, and on May I7 a small island, called Jeannette Island, was sighted in $76^{\circ} 47^{\prime} 28^{\prime \prime} \mathrm{N}$. lat. and $159^{\circ} 20^{\prime} 45^{\prime \prime} \mathrm{E}$, long. It was a rocky hill, covered with snow, situated on the eastern flank of a high mountain. Two days later another island was discovered towards the west, and an expedition under Mr. Melville reached it, with many difficulties, and landed on it on June 3, I88I. It was called Henrietta Island, and is situated under $77^{\circ} 8^{\prime} \mathrm{N}$. lat. and $157^{\circ} 43^{\prime} \mathrm{E}$. long. ; it is rocky, and 2500 to 3000 feet high; the rocks are covered with nests of birds, but the vegetation is very poor, consisting of lichens and mosses, and of one species of phanerogam ; all the isiand was covered with a sheet of ice and snow 50 to 100 feet thick, and a mighty glacier reached the sea on the north coast. As is known, on June I3, under $77^{\circ} 30^{\prime}$ N. lat., and $155^{\circ} \mathrm{E}$. long., the Jeannette was lost, the depth of the sea being there 38 fathoms. The crew, divided in three parties, went south, but ten days later they perceived that, owing to the drift of the ice, they had still advanced 27 miles north-west, being under $77^{\circ} 42^{\prime} \mathrm{N}$. lat. That was the highest latitude reached by the expedition. On July 9 they perceived land, and after a hard journey, reached it at a promontory they called Cape Emma $\left(76^{\circ}\right.$ $38^{\prime} \mathrm{N}$. lat., $148^{\circ} 2 \mathrm{O}^{\prime} \mathrm{E}$. lat.). This island, which received the name of Bennett, is a high mass of basalt, covered with glaciers; the island was crossed by a party, after two days' travel, and the north coast proved to be more hospitable than the south; it has several valleys covered with grass, where reindeer bones and drift-wood were found; lignite was discovered on the south coast, aud it is said that it would be quite useful for steamers. Dr. Ambler here collected fossils, as well as many amethysts and opals, but they were lost. The gulls were so numerous and so tame that hundreds of them were killed with sticks; the tides were regular, but very small, the level changing only two and three feet. The sea was free of ice in the west and south, and even in the north-west a "water-sky" was seen, so that M. Danenhauer supposes that Bennett Island would be a good starting-place for future arctic expeditions. It was only on August 30 that the expedition discovered the first traces of men on the Faddeyeff Islands; and its further advance towards the delta of the Lena is well known. The scientific results of the Jeannette expedition cannot be yet completely appreciated, observes Herr Wichmann, but the note-books and surveys of its members having been preserved, as well as a good part of the collections, it is to be expected that they will contribute to a great extent to increase our knowledge of this part of the Arctic Ocean. The discovery of three new islands confirms the statements of Sannirikoff, who stated he saw land from the Faddeyeff Islands, and renders probable the existence of a whole archipelago in that part of the ocean. The exploration of the fauna and flora of the New Siberian Islands, which never was done before during the summer, promises interesting results. The problematical polynias; which stopped the advance of the sledge parties of Hedenström, Wrangel, and Anjou are not due to some warm currents, such having not been noticed during the temperatureobservations of the Jeannetle; they are simple openings in the ice, such as are observed elsewhere. Finally, the search expedition must give most important corrections to the maps of the Siberian coast between the Olenek and the Yana rivers, which has not been visited for sixty years ; the observations of the American expedition will correct many of the observations of Lieut. Anjou. We may add to these expectations of Herr Wichmann that, as the Arctic law that "each polar expedition safely reaches the points which were sighted by the preceding one," will probably be true also for the North Siberian Seas, we must soon expect new and important discoveries in that direction, now that the way was opened to explorers of those parts of the Arctic seas.

\section{NOTES}

WE regret to learn that $M$. Joseph Liouville, the editor of the Fournal de Mathematiques, died in Paris on Septem. ber 7 at the age of seventy-six years. For some time back he had retired from his editorship and appointed M. Resal, a member of the Institute, as his successor. M. Liouville was born in St. Omer, admitted to the Polytechnic School in 1825, and appointed in 1829 an engineer of the Ponts-et-Chaussées. He soon resigned in order to devote himself entirely to the study of pure mathematiss, He was elected in 1839 a member of the section of geometry in the Paris Academy. In I 848 he was sent by the electors of the Meurthe to the National Assembly, where he supported Arago's policy. In 1862 he was appointed a member of the Bureaux des Longitudes.

A Monument to Becquerel, the French electrician, will be inaugurated this month at Chatilion.

Dr. Lems'rRöm, of Helsin yfors, begins to-morrow a series of measurements of terrestrial currents, which measurements will be continued the Ist and $15^{\text {th }}$ of each month. They u ill be made on two telegraphic lines, one of which, between Torneo and Helsingfors, runs north and south, and the other, between Mariehann, on the Alland islands, and Kexholm, runs west and east.

THE Council of the Parkes Museum have just acquired new premises in Margaret Street, Cavendish Square, to which the museum is to be removed from University College as soon as the alterations and additions, which are now being made under the direction of Mr. Mark H. Judge, A.R.I.B.A., are completed. The new museum will consist of a central hall, suitable for meetings and lectures, a library and corridors, all lighted from the top and well suited for exhibition purposes. The meetings 